\title{
Role of myosin Va on HTLV-1 p8I protein's traffic to cell surface
}

\author{
Jaqueline G Jesus ${ }^{1 *}$, Rui MPS Júnior ${ }^{2}$, Maria F de Castro-Amarante ${ }^{3}$, Simone K Haddad ${ }^{4,5}$, Enilza M Espreáfico ${ }^{2}$, \\ Genoveffa Franchini ${ }^{3}$, Luiz CJ Alcântara ${ }^{1}$ \\ From 17th International Conference on Human Retroviruses: HTLV and Related Viruses \\ Trois Ilets, Martinique. 18-21 June 2015
}

HTLV-1 ORF-I encodes the 99 amino acid p12 protein which can be proteolytically cleaved at the amino terminus to generate the $\mathrm{p} 8$ protein. The first proteolytic cleavage removes the ER retention/retrieval signal at the amino terminus of $\mathrm{p} 12$, while the second cleavage generates the $\mathrm{p} 8$ protein. The $\mathrm{p} 12$ protein localizes to cellular endomembranes, within the ER and Golgi apparatus, while $\mathrm{p} 8$ traffics to lipid rafts at the cell surface and is recruited to the immunological synapse upon T-cell receptor (TCR) ligation. In secretory vesicle transport, vesicles produced as post-Golgi are moved along the cytoskeleton by motor proteins. The unconventional myosin motor, myosin $\mathrm{V}$, moves several cargoes including secretory vesicles, synaptic vesicles, and the endoplasmic reticulum. To understand if p8 traffics from Golgi apparatus to cell surface on a myosin Va dependent manner, Jurkat $\mathrm{T}$ cells were transfected with pMEp12 plasmids which express variants (p12WT, p12 $\Delta 29$ and p12G29S) of the fusion protein of HTLV-1 p12I tagged with the influenza hemagglutinin (HA1) tag and with the Myo Va full-tail neuronal-eGFP conjugated (MyoVa FTNeu-eGFP) plasmid which expresses a negative dominant of myosin $\mathrm{Va}$ and competes for intracellular ligands with cellular putative myosin. Both $\mathrm{p} 12 / \mathrm{p} 8$ and myosin Va proteins intracellular localization were analyzed by indirect immunofluorescence assay using antibodies against the HA-tag and the Myo Va protein. Confocal microscopy and image collection was performed by using a p12I/p8I proteins Zeiss LSM 780 microscope (Carl Zeiss Optical, Chester, Va.) with Adobe Photoshop CC software. It was reported p12I expression in Jurkat $\mathrm{T}$ as previous described was shown in perinuclear region which might be RE and Golgi apparatus and that p12I/p8I and MyoVa

\footnotetext{
* Correspondence: jaquelinegoesdejesus@gmail.com

${ }^{1}$ Gonçalo Moniz Research Center, Oswaldo Cruz Foundation, R. Waldemar

Falcão, 121, Candeal Salvador, Bahia, 40296-710, Brazil

Full list of author information is available at the end of the article
}

proteins colocalizes, however only when MyoVa FTNeueGFP was simultaneously expressed with pMEp12 plasmids, p12I/p8I localization showed to be altered from dots dispersed all over cytoplasm and cell surface to form cytoplasmic aggregates independently on variant of p12I expressed, suggesting that myosin Va plays an important role on traffics of p8I from Golgi to cell surface.

\section{Authors' details}

'Gonçalo Moniz Research Center, Oswaldo Cruz Foundation, R. Waldemar Falcão, 121, Candeal Salvador, Bahia, 40296-710, Brazil. ${ }^{2}$ Faculty of Medicine of Ribeirão Preto, University of São Paulo - Av. Bandeirantes, 3900, Monte Alegre - Ribeirão Preto, São Paulov 14049-900, Brazil. ${ }^{3}$ Animal Models and Retroviral Vaccines Section, National Cancer Institute, National Institute of Health, Bethesda, USA. ${ }^{4}$ Faculty of Pharmaceutics of Ribeirão Preto, University of São Paulo - Av. do Café, s/no, Ribeirão Preto, São Paulo, 14040-903, Brazil. ${ }^{5}$ Blood Center of Ribeirão Preto - R. Tenente Catão Roxo, 2501, Ribeirão Preto, São Paulo, 14051-140, Brazil.

Published: 28 August 2015

doi:10.1186/1742-4690-12-S1-P1

Cite this article as: Jesus et al:: Role of myosin Va on HTLV-1 p8l protein's traffic to cell surface. Retrovirology 2015 12(Suppl 1):P1.

Submit your next manuscript to BioMed Central and take full advantage of:

- Convenient online submission

- Thorough peer review

- No space constraints or color figure charges

- Immediate publication on acceptance

- Inclusion in PubMed, CAS, Scopus and Google Scholar

- Research which is freely available for redistribution

Submit your manuscript at www.biomedcentral.com/submit
() Biomed Central 